\title{
Wzmocnione publikacje: nowy model wsparcia komunikacji naukowej ${ }^{1}$
}

\author{
Edyta Kędzierska \\ Biblioteka Gtówna Politechniki Warszawskiej
}

\begin{abstract}
Abstrakt
Cel/teza: Celem artykułu jest przedstawienie koncepcji wzmocnionych publikacji (ang. enhanced publications), które to mogą mieć wpływ na polepszenie i zoptymalizowanie komunikacji naukowej. Wzmocnione publikacje są złożonymi obiektami cyfrowymi zawierającymi publikacje $\mathrm{w}$ formie standardowych książek, artykułów, raportów oraz powiązane z nimi dodatkowe elementy takie jak: surowe dane badawcze, nagrania filmowe i dźwiękowe, algorytmy, plany, modele, komentarze, itp. Koncepcja/metody badań: Przeprowadzono badanie ankietowe wśród polskich instytucji naukowych i badawczo-rozwojowych, których celem było zbadanie poziomu znajomości i wykorzystania wzmocnionych publikacji. Scharakteryzowano sposoby zarządzania zasobami danych badawczych: ich produkcję, przechowywanie, archiwizowanie i udostępnianie oraz określono wykorzystanie i opinie na temat modelu otwartego dostępu.

Wyniki i wnioski: Wśród polskich instytucji badawczych tworzenie wzmocnionych publikacji jest działaniem raczej nie często realizowanym. Wprawdzie większość instytucji deklaruje stosowanie praktyki powiązywania danych badawczych z publikacjami jednak głównie dzieje się to poprzez zamieszczanie jedynie informacji o dostępie do danych źródłowych, a nie cyfrowych obiektów w otwartych zasobach. Oryginalność/wartość poznawcza: Przeprowadzone badania są częścią projektu realizowanego w ramach współpracy z krajami Grupy Wyszehradzkiej, którego celem było scharakteryzowanie specyfiki komunikacji naukowej w krajach członkowskich oraz określenie kierunków rozwoju. Artykuł przybliża koncepcję wzmocnionych publikacji, które na gruncie polskim są jeszcze stosunkowo mało znane.
\end{abstract}

\section{Słowa kluczowe}

Wzmocnione publikacje. Otwarty dostęp. Otwarte dane. Komunikacja naukowa.

Otrzymany: 8.12.2014. Poprawiony: 25.06.2015. Zaakceptowany: 29.06.2015.

\section{Wprowadzenie}

Współczesna komunikacja naukowa w dużej mierze rozwija się przy udziale technologii informatycznych. Tradycyjne kanały rozpowszechniania dorobku naukowego (kontakty osobiste, publikacje papierowe, wystąpienia na konferencjach, itp.) zostają w coraz większym stopniu uzupełniane, a może nawet zastępowane przez komunikaty w środowisku

\footnotetext{
${ }^{1}$ Materiał został przygotowany na podstawie danych zebranych w ramach projektu: Enhancing scholarly communication: National initiatives to manage research data in the V4 countries finansowanego z Funduszu Wyszehradzkiego. Projekt został zaprezentowany na konferencji: 7th Annual Conference on Grey Literature and Repositories (Praga, 22.11.2014) oraz w publikacji: Görögh E. at al. (2013). Enhancing scholarly communication. National initiatives to manage research data in the V4 countries.
}

Dane badawcze dostępne pod adresem: http://dx.doi.org/10.6084/m9.figshare.1466764 
Internetu (publikacje w otwartych czasopismach, blogi, serwisy naukowe). Większą wagę zaczęto przykładać do dynamiki procesu komunikacji naukowej, możliwości niemalże natychmiastowego publikowania rezultatów swoich prac badawczych, szybkiego dostępu do bieżących informacji i nowości z danej dziedziny wiedzy, a także możliwości dystrybucji informacji na niespotykaną dotychczas skalę, przy jednoczesnej redukcji kosztów. W tym aspekcie, możliwości jakie stwarza środowisko Internetu zdecydowanie przeważają nad tradycyjnymi formami papierowymi.

Dla rozwoju komunikacji naukowej kluczowe są nie tylko publikacje stanowiące efekt końcowy prowadzonych badań, ale także wszystkie informacje wytworzone podczas procesu badawczego (dane badawcze, narzędzia, materiały pomocnicze, idee, pytania badawcze) a także odbiór tych publikacji przez środowisko naukowe (komentarze, recenzje, dyskusje, opinie). Uwzględnienie wszystkich elementów pozwala na skonstruowanie szerszego kontekstu badań, gwarantuje przejrzystość, umożliwia ich lepsze zrozumienie, weryfikację oraz dalsze wykorzystanie. Dopiero zapewnienie swobodnego i nieograniczonego dostępu do zebranych i połączonych w sieć wzajemnych powiązań elementów składowych procesu badawczego, może w istotny sposób wpłynąć na rozwój nauki.

\section{Otwarta nauka - dostęp do publikacji i danych badawczych}

Idea otwartej nauki zakłada swobodny dostęp zarówno do końcowych rezultatów prac badawczych, czyli publikacji, jaki i stosowanie otwartego modelu również na innych etapach działań naukowych (Szprot, red. 2014, 27). Otwarty dostęp (Open Access - OA) do treści naukowych oznacza swobodne czytanie, zapisywanie, kopiowanie, drukowanie, rozpowszechnianie, wyszukiwanie, linkowanie oraz wykorzystywanie zgodnie z prawem bez finansowych, prawnych czy technicznych ograniczeń, różnych od tych związanych z dostępem do Internetu (Kozierski et al., 2013, 7).

O ile kwestia otwartego dostępu do publikacji naukowych jest już od dawna znana, o tyle dostęp do danych badawczych wydaje się dopiero przebijać do powszechnej świadomości. Wiąże się to m.in. z funkcjonującym przekonaniem o tym, co uważa się za wynik prac naukowych. Dotychczas osiągnięcia naukowe opierały się na publikacjach, ich liczbie, jakości czasopism w jakich się ukazywały oraz liczbie cytowań w czasopismach naukowych (Hofmokl et al., 2009). Dane badawcze, na podstawie których powstają publikacje, są także ważnym elementem procesu badawczego. Otwarte dane to dane powszechnie i swobodnie dostępne dla wszystkich, w całości lub w części, w możliwym do przetwarzania formacie, gotowe do pobrania, wielokrotnego wykorzystania i dalszego rozpowszechniania. Swobodny dostęp do danych źródłowych ciągle ograniczony jest różnymi czynnikami ekonomicznymi, prawnymi i technicznymi: m.in. prawami własności intelektualnej, zyskami wydawców, brakiem odpowiednich standardów publikacji danych, co utrudnia ich zbieranie, przechowywanie i agregację (Hofmokl et al., 2009, 58). Dodatkowo istnieje wiele obaw hamujących naukowców przed udostępnieniem danych badawczych: pojawia się niepokój związany z możliwością utraty kontroli nad danymi, tego, że ktoś inny może je lepiej wykorzystać, mogą zostać wykryte błędy w danych i tym samym może zostać podważona ich jakość, mogą zostać one źle zinterpretowane i niewłaściwie wykorzystane, często badacze nie wiedzą, jak i gdzie mogą składować zebrane dane (Bednarek-Michalska, 2012). 
Stopniowo rośnie jednak liczba inicjatyw promujących zapewnienie otwartego dostępu do danych badawczych. W 2004 r. organizacja OECD przyjęła Deklarację w kwestii dostępu do danych badawczych finansowanych ze środków publicznych (OECD, 2007), w której to rekomendowane jest przyjęcie zasad otwartości, przejrzystości i interpretacyjności danych. Horyzont 2020 - program finansowania badań naukowych i innowacji w Unii Europejskiej - zawiera wymóg upowszechniania wyników badań w Internecie oraz pilotaż związany z upublicznianiem surowych danych badawczych (Horizon, 2020, 2013).

Obecnie prace nad rozwojem idei otwartych danych skupiają się głównie wokół stworzenia właściwego modelu prawnego, który pozwoli pokonać bariery określone przez obowiązujący stan własności intelektualnej oraz wypracowanie modelu zapewniającego techniczną dostępność danych: standardy metadanych, metody agregacji, wyszukiwania i opracowania danych (Hofmokl et al., 2009, 60). Brak otwartego dostępu do danych badawczych może mieć negatywny wpływ na rozwój komunikacji naukowej m.in. poprzez wzrost kosztów badań, mniejszy zakres badań ze względu na trudności w pozyskiwaniu danych, ograniczenie współpracy oraz wymiany doświadczeń, gorszą jakość danych poprzez brak ich publicznej weryfikacji (Hofmokl et al., 2009, 59).

\section{Enhanced publications - wzmocnione publikacje}

Przez termin enhanced publications (EP) rozumie się złożone obiekty cyfrowe zawierające publikacje w formie np. standardowych książek, artykułów, raportów, itp. oraz powiązane z nimi dodatkowe elementy, m.in. dane badawcze, nagrania filmowe i dźwiękowe, algorytmy, plany, modele i inne materiały wizualne, komentarze, recenzje, dyskusje. W literaturze anglojęzycznej pojęcie to zostało już stosunkowo dobrze opisane i scharakteryzowane (np.Godtsenhoven, van et al., 2009). W literaturze polskiej trudno jednak znaleźć informacje na ten temat. Określenie enhanced publications można przetłumaczyć jako wzmocnione, zwiększone czy też poszerzone publikacje. Każde z tych określeń wydaje się w sposób właściwy ujmować sens opisywanego zjawiska². Owe dodatkowe produkty prac badawczych stanowią ważny komponent publikacji - ubogacają ją, obrazują szerszy kontekst działań, uwiarygadniają uzyskane wyniki i wyciągnięte wnioski, zwiększają czytelność i pomagają zrozumieć badania, pozwalają na weryfikację i wielokrotne wykorzystanie danych i materiałów badawczych.

Kluczem do tworzenia wzmocnionych publikacji nie jest samo zamieszczenie materiałów w Internecie, ale ich wzajemne powiązanie i zbudowanie właściwej infrastruktury relacyjnej (Godtsenhoven, van et al., 2009). Można odnaleźć wiele publikacji w otwartych zasobach Internetu, zaczynają się pojawiać także miejsca (np.repozytoria) przechowywania surowych danych badawczych i materiałów uzupełniających, powstają blogi i serwisy tematyczne, gdzie toczy się ożywiona wymiana opinii - jednak brak jest zaznaczonych relacji pomiędzy materiałami i publikacjami, które są powiązane tematycznie. Zdaniem autorki istotne jest wskazywanie sensownych i jednoznacznych związków jakie zachodzą między elementami, które wprawdzie mogą funkcjonować jako odrębne całości, ale jednak dopiero w kontekście wzajemnych korelacji uwidaczniają dodatkowe informacje.

\footnotetext{
${ }^{2} \mathrm{~W}$ artykule będę posługiwać się terminem wzmocnione publikacje.
} 
W obliczu nieustanie rosnącej liczby materiałów zamieszczanych w Internecie tworzenie sieci wzajemnych powiązań i odniesień pozwala na organizację zasobów oraz integrację treści naukowych (Godtsenhoven, van et al., 2009). Wzmocnione publikacje sprzyjają tym samym wydajności komunikacji naukowej, poprzez ujednolicenie i zintegrowanie treści, obrazują wzajemne powiazania między pokrewnymi obiektami i tym samym zaznaczają szerszy kontekst prac badawczych oraz ich rezultatów.

Publikacje zamieszczane w Internecie w większości przypadków są odwzorowaniem swoich papierowych odpowiedników i odznaczają się statycznością. Pomimo dystrybucji w środowisku elektronicznym nie są wykorzystywane możliwości jakie stwarzają współczesne technologie informatyczne. Dodatkowym atutem wzmocnionych publikacji jest ich interaktywność, co pozwala nie tylko na pasywny odbiór treści, ale także umożliwia oddziaływanie na rodzaj i formę komunikatu.

Adriaansen i Hooft (b.d.) wskazują na typowe elementy, którymi powinny odznaczać się wzmocnione publikacje:

- wskazanie cyfrowej postaci źródłowych danych badawczych (np.link do miejsca przechowywania, załączony plik Microsoft Excel, itp.),

- załączone dodatkowe materiały (tabele, wykresy, zdjęcia, nagrania dźwiękowe, wideo, itp.),

- interaktywne treści (np. tabele, rysunki, wykresy),

- linki odsyłające do cytowanych publikacji,

- wskazania publikacji cytujących dany materiał,

- komentarze dotyczące całości lub części,

- wskazanie relacji z innymi publikacjami, plikami, itp.,

- nawigacja po publikacji (np.przy pomocy spisu treści),

- dane bibliograficzne,

- możliwość pobrania w tradycyjnym formacie pdf.

Dodatkowo wzmocnione publikacje powinny dawać stałą możliwość rozwoju, czyli dodawania kolejnych obiektów cyfrowych w dowolnym czasie i zapewniać widoczność w środowisku Internetu (Verhaar, 2009).

$\mathrm{Na}$ arenie międzynarodowej pojawiają się projekty (np. The Dutch SURFshare programme $^{3}$, The European DRIVER II Project ${ }^{4}$ ) dążące do stworzenia jednolitej płaszczyzny scalającej repozytoria publikacji naukowych i repozytoria danych badawczych. Inicjatywy te zmierzają do poprawy dostępu do dorobku naukowego oraz zapewnienia naukowcom możliwości i narzędzi dzielenia się wynikami swoich prac i korzystania z osiągnieć innych (Hoogerwerf, 2009).

\section{Sytuacja w Polsce}

W Polsce brak jest jednolitej strategii rozwoju idei Open Access na poziomie ogólnokrajowym. W 2004 r. Ministerstwo Nauki i Szkolnictwa Wyższego (MNiSW) podpisało deklarację OECD dotyczącą otwartego dostępu do rezultatów badań finansowanych ze środków

\footnotetext{
${ }^{3}$ http://www.surffoundation.nl/en

${ }^{4}$ http://www.driver-community.eu
} 
publicznych (Szprot, red., 2014, 14). Dokument ten wprawdzie poszerzył świadomość istnienia OA, jednak nie wdrażał konkretnych rozwiązań. Dopiero w 2012 r. MNiSW zadeklarowało wsparcie dla idei otwartego dostępu. Istotny wydźwięk miała także uchwała z lipca 2013 r. Prezydium Polskiej Akademii Nauk oraz Konferencji Rektorów Polskich Szkół Akademickich, wspierająca drogę zieloną (tworzenie repozytoriów) w ruchu Open Access. Ważnym krokiem w kierunku szerszej dostępności prac naukowych, jest wprowadzona w lipcu 2014 r. poprawki do ustawy Prawo o szkolnictwie wyższym, która obliguje wszystkie uczelnie wyższe do umieszczania w centralnym (krajowym) repozytorium prac dyplomowych obronionych od stycznia 2009 r.

Z danych za rok 2014 wynika, że w Polsce funkcjonowało ponad 900 tytułów czasopism elektronicznych w otwartym dostępie (49.2\% wszystkich tytułów). 71 czasopism jest udostępnianych na licencjach Creative Commons (Szprot, red., 2014, 57-59). Funkcjonuje 117 bibliotek cyfrowych rejestrujących ponad $2 \mathrm{mln} 200$ tys. publikacji (Federacja...). Działają także 23 repozytoria cyfrowe gromadzące publikacje naukowe (Szprot, red., 2014, 31). Brak jest informacji na temat repozytoriów gromadzących surowe dane badawcze. Stopniowo rośnie liczba instytucji i projektów podejmujących działania zmierzające do wprowadzenia na szerszą skalę modelu Open Access. Otwarty model publikowania naukowego promuje kilka wydawnictw naukowych, takich jak ViaMedica, Termedia czy Versita (obecnie De Gruyter Open). Razem wydają one kilkadziesiąt tytułów w modelu Open Access. Powstają inicjatywy promujące działania w modelu OA: np. Otwórz książę ${ }^{5}$, Wolne podręczniki ${ }^{6}$ (Hofmokl et al., 2009).

\section{Projekt Enhancing scholarly communication}

W ramach środków pozyskanych z Funduszu Wyszehradzkiego, w 2014 r. zostały przeprowadzone badania mające na celu zdiagnozowanie i opisanie specyfiki komunikacji naukowej w krajach członkowskich Grupy Wyszehradzkiej. W realizację projektu „Enhancing scholarly communication: National initiatives to manage research data in the V4 countries" zaangażowały się biblioteki naukowe (czyli instytucje szczególnie zainteresowane kwestiami przechowywania i udostępniania rezultatów prac badawczych) z czterech krajów Grupy Wyszehradzkiej: Biblioteka Uniwersytetu w Debreczynie (Węgry), Biblioteka Wydziału Chemicznego Słowackiego Uniwersytetu Technicznego (Słowacja), Narodowa Biblioteka Techniczna (Czechy) i Biblioteka Główna Politechniki Warszawskiej (Polska). Współpraca polegała na opracowaniu wspólnego narzędzia badawczego (kwestionariusza ankiety), przeprowadzeniu badań ankietowych wśród instytucji badawczych i naukowych w każdym z krajów, sporządzeniu raportów końcowych oraz wspólnym zaprezentowaniu wyników.

Cele badań $\mathrm{EP}^{7}$ oscylowały wokół trzech głównych obszarów:

1. Model OA - zbadanie czy publikacje naukowe pracowników instytucji są zamieszczane w otwartym dostępie oraz poznanie opinii na temat przydatności tego modelu.

\footnotetext{
${ }^{5}$ http://otworzksiazke.pl

${ }^{6} \mathrm{http}: / /$ wolnepodreczniki.pl

$7 \mathrm{~W}$ artykule badania realizowane w ramach projektu "Enhancing scholarly communication: National initiatives to manage research data in the V4 countries" będą określane jako badania EP.
} 
2. Zarządzanie zasobami danych badawczych - zbadanie zasad zarządzania, czyli: produkcji, przechowywania, archiwizowania, wykorzystywania i udostępniania surowych danych badawczych i materiałów w środowisku naukowym.

3. Wzmocnione publikacje - zbadanie poziomu znajomości i wykorzystania wzmocnionych publikacji.

Starano się znaleźć odpowiedzi na pytania:

1. Jakie dane są produkowane w polskich instytucjach, gdzie i jak długo są przechowywane, kto jest za nie odpowiedzialny?

2. Czy dane badawcze są łączone z publikacjami opracowanymi na ich podstawie, czy są ponownie wykorzystywane i udostępniane dla instytucji zewnętrznych?

3. Czy dane i publikacje są upubliczniane w otwartych zasobach Internetu?

4. Jaka opinia panuje w środowisku naukowym na temat przydatności modelu Open Access oraz stworzenia otwartego międzyinstytucjonalnego repozytorium danych badawczych?

Odpowiedzi na te pytania miały określić specyfikę produkcji i dystrybucję treści naukowych i wiedzy w polskim środowisku naukowym.

Badania polskich instytucji naukowych i badawczo-rozwojowych zostały przeprowadzone metodą CAWI ${ }^{8}$ za pomocą kwestionariusza ankiety przygotowanego i dystrybuowanego w wersji elektronicznej. Jednostkami analizy były poszczególne instytucje, zgromadzono informacje dotyczące form pracy i zasad funkcjonowania organizacji, a nie indywidualne opinie osób.

Według Rocznika Statystycznego GUS (Dmochowska, red., 2013) w 2013 r. zarejestrowano w Polsce 2733 jednostki naukowe i badawczo-rozwojowe. Badaniem nie objęto: komercyjnych podmiotów gospodarczych, niepublicznych szkół wyższych, muzeów, archiwów, bibliotek, seminariów. Do populacji zaliczono instytucje funkcjonujące w sferze publicznej, których obszar działań głównie (lub w znacznym stopniu) skupia się na pracach badawczych i rozwojowych. Instytucje spełniające powyższe warunki sklasyfikowano w trzech grupach: jednostki naukowe i badawczo-rozwojowe (instytuty, ośrodki badawczo-rozwojowe, laboratoria, itp.), instytuty naukowe Polskiej Akademii Nauk, szkoły wyższe (publiczne) - w sumie 418 instytucji. Liczebność próby badawczej została wyznaczona za pomocą metod statystycznych i wyniosła 268 jednostek (przy poziomie ufności 0.90 i zakładanym poziomie błędu 0.05).

Badanie trwało dwa miesiące i zgromadzono 207 wypełnionych ankiet. Uwzględniając uzyskany $77 \%$ poziom realizacji próby badawczej oraz przeprowadzone analizy dotyczące reprezentatywności próby pod względem typu instytucji ${ }^{9}$ uznano, iż badania zostały przeprowadzone na próbie badawczej zbliżonej do próby reprezentatywnej. Badania mają jednak charakter eksploracyjny i nie uprawniają do uogólnień wniosków na całą populację.

\footnotetext{
${ }^{8}$ CAWI - metoda zbierania informacji w badaniach ilościowych, w której respondent jest proszony o wypełnienie ankiety w formie elektronicznej.

9 Porównano strukturę próby badawczej ze strukturą populacji z uwzględnieniem zmiennej określającej typ instytucji. Przyjęto, iż próba badawcza jest reprezentatywna jeżeli udziały procentowe poszczególnych kategorii w próbie nie różnią się więcej niż o 5\% od udziałów procentowych tych samych kategorii w populacji. Stwierdzono, że w 2 na 3 wyodrębnionych kategoriach różnica ta była przekroczona o ok. 2 punkty procentowe. Na tej podstawie uznano, że próba badawcza jest zbliżona do próby reprezentatywnej.
} 


\subsection{Zarzadzanie zasobami surowych danych badawczych winstytucjach}

Surowe dane badawcze to dane powstające w wyniku badań naukowych. Są one gromadzone przez badaczy za pomocą różnych metod, standardów czy procedur. W zależności od specyfiki danej dyscypliny naukowej oraz stosowanych metod badawczych, działalność naukowo-badawcza prowadzi do gromadzenia, przetwarzania i udostępniania różnych typów danych, mogą to być dane ilościowe lub jakościowe, dane liczbowe, tekstowe, fotografie, pliki audio/wideo itp. W badaniach EP najwięcej, bo ponad 60\% instytucji stwierdziło, iż produkuje dane m.in. z badań pomiarowych i/ lub eksperymentalnych. Prawie $20 \%$ mniej placówek wskazywała na wyniki z badań testujących i statystycznych (trzecia i czwarta najczęściej wybierana odpowiedź). Dane z badań społecznych produkuje ok. $32 \%$ instytucji.

Dane badawcze wytwarzane w instytucjach związane są zarówno z typem jednostki, jak i uprawianą dyscyplina wiedzy. Według Rocznika Statystycznego GUS za rok 2014, ok. $52 \%$ osób zatrudnionych w działalności badawczej i rozwojowej to specjaliści z zakresu nauk inżynieryjnych i technicznych, 15\% nauk społecznych, 15\% nauk medycznych, $11 \%$ humanistycznych, 7\% rolniczych (Dmochowska, red., 2014). Struktura ta pokrywa się $\mathrm{w}$ dużym stopniu z danymi uzyskanymi z badań EP. Instytucje wskazywały dyscypliny wiedzy, w obszarze których prowadzą swoją działalność. Około $48 \%$ wskazań dotyczyło nauk technicznych, $22 \%$ społecznych, $16 \%$ humanistycznych, $11 \%$ rolniczych i $9 \%$ medycznych.

Najczęściej stosowanym formatem zapisu dla danych jest format pdf, stosuje go ponad 86\% instytucji. Drugi pod względem liczby wskazań jest format doc. Także większość materiałów zdeponowanych w polskich repozytoriach lub w otwartych czasopismach jest $\mathrm{w}$ formacie pdf. Wyjątkowo można znaleźć pliki w formacie $\mathrm{DjVu}$ (standardowy format w polskich bibliotekach cyfrowych) czy inne formaty (Szprot, red., 2014, 41). Format pdf jest jednak formatem zamkniętym, który nie pozwala na modyfikacje, zdecydowanie utrudnia to dalsze przetwarzanie i wykorzystywanie danych. Dane gromadzone i przechowywane przez polskie instytucje dalekie są od standardów, które zalecają zapisywanie danych w formatach otwartych umożliwiających ich ponowne użytkowanie (Open Data... , 2012).

Dane badawcze powinny być przechowywane w taki sposób, aby zapewnione było ich bezpieczeństwo i zminimalizowane ryzyko ich utraty. Zarządzanie danymi ma zapewnić integralność badań i replikację danych. Dane powinny być archiwizowane w sposób kompletny, co ma zagwarantować ich autentyczność i wiarygodność. Właściwe przechowywanie danych ma służyć oszczędności czasu i środków w perspektywie długofalowej, a także wpłynąć na efektywność badawczą poprzez m.in. upowszechnianie danych i umożliwienie ich ponownego wykorzystania (Bednarek-Michalska, 2013).

W zdecydowanej większości instytucji, dane badawcze przechowywane są w wewnętrznych, dostępnych tylko dla pracowników instytucji miejscach (na własnych stanowiskach pracy i/ lub centralnym serwerze - dwie najczęściej wskazywane odpowiedzi w badaniach EP). Jedynie ok. $12 \%$ jednostek wymieniało otwarte zasoby (własne lub zewnętrzne). Widać tutaj wyraźną tendencję polskich instytucji naukowych i badawczo-rozwojowych do preferowania sposobów przechowywania danych badawczych zamkniętych na zewnątrz i ograniczonych do danej instytucji, a nawet do poszczególnych jej pracowników. Dodatkowo, to głównie pracownicy (71\% instytucji) sami są odpowiedzialni za zebrane dane badawcze, za ich przechowywanie i archiwizowanie. W drugiej kolejności respondenci wskazywali, iż to wyznaczone osoby w bibliotekach zajmują się danymi uzyskanymi w wyniku prac 
badawczych. Jednak wariant ten był średnio dwukrotnie rzadziej wskazywany niż najczęściej padająca odpowiedź. Z zebranych informacji wynika, iż w polskich instytucjach naukowych zarządzanie danymi badawczymi w większości odbywa się w sposób mało usystematyzowany i raczej zdecentralizowany. Preferowane są rozwiązania polegające na samodzielnej odpowiedzialności poszczególnych pracowników i przechowywaniu danych w obrębie instytucji macierzystej. Ok 40\% respondentów deklaruje przejawy zarządzania bardziej scentralizowanego (dane zamieszczane na wspólnym serwerze, nadzorowane przez wyznaczone osoby). 13\% instytucji określiło, iż zamieszczają swoje dane w otwartych zasobach własnych lub zewnętrznych. Ponadto instytucje w niewielkim stopniu przejawiają chęć zmiany takiej sytuacji, 80\% jednostek nie planuje wprowadzania modyfikacji dotyczących sposobu przechowywania danych badawczych.

W zdecydowanej większości instytucji (80\%) dane badawcze są ponownie wykorzystywane wewnątrz danej placówki, zarówno w innych projektach badawczych, jak i przez innych pracowników zatrudnionych w danej jednostce. Około 70\% polskich instytucji udostępnia swoje dane badawcze pracownikom naukowym z jednostek zewnętrznych. Najczęstszym kanałem przekazywania danych jest poczta mailowa lub osobisty odbiór. Preferowane są zatem rozwiązania polegające na indywidualnych ustaleniach i porozumieniach, rzadziej instytucje stosują możliwość swobodnego pobierania danych. W zdecydowanej większości (82\% w badaniu EP) polskie instytucje naukowe nie wykorzystują publicznych licencji dla udostępniania i uwidaczniania danych badawczych.

Wśród uzasadnień faktu nieudostępniania danych badawczych na zewnątrz, często wskazywano na poufność zebranych danych lub tajemnicę służbową. W niektórych przypadkach dane są udostępniane jedynie za zgodą odpowiednich jednostek: kierownictwa, zleceniodawcy, autora lub na mocy zawartych porozumień. Stwierdzono także, iż dane te są własnością naukowca, instytucji, lub zleceniodawcy. Niekiedy także specyfika zebranych danych utrudnia ich upowszechnianie. Część instytucji wskazywała na ochronę własności intelektualnej lub prawo autorskie. Przyczynę rezygnacji z udostępniania danych uzasadniano także: brakiem odpowiedniego oprogramowania zabezpieczającego dostęp, udostępnianiem jedynie na miejscu w bibliotece, zgodnie z klauzulą dostępności, udostępnianiem danych przetworzonych w postaci artykułów.

\subsection{Wykorzystanie modelu Open Access}

Stopień wykorzystania modelu Open Access przez polskie środowisko naukowe kształtuje się na poziomie przeciętnym. Prawie połowa instytucji biorących udział w badaniu EP (47.82\%) zadeklarowała, iż publikacje ich pracowników naukowych są zamieszczane w otwartych internetowych archiwach lub repozytoriach. Około 16\% instytucji określiło, iż trudno jednoznacznie stwierdzić czy pracownicy korzystają z tego modelu. Odpowiedzi z $36 \%$ instytucji wskazywały, że pracownicy nie zamieszczają prac naukowych w OA. Natomiast z badań ankietowych przeprowadzonych na początku 2014 r., skierowanych do polskich naukowców wynika, iż $60 \%$ badaczy zamieszcza regularnie lub sporadycznie swoje prace w zasobach OA (Szprot, red., 2014).

Wyniki uzyskane z badań instytucji naukowych i badań skierowanych do indywidualnych naukowców wydają się być zbliżone. Rozbieżności mogą wynikać z faktu, iż w większości polskich instytucji naukowych i badawczo-rozwojowych nie są prowadzone rejestry 
dotyczące zamieszczania publikacji pracowników naukowych w otwartych zasobach Internetu. W związku z tym przedstawiciele instytucji naukowych raczej intuicyjnie wypowiadali się na temat publikowania w OA przez pracowników naukowych ich jednostek.

Wśród instytucji, których pracownicy zamieszczają swoje materiały w zasobach OA nieco ponad 3\% stwierdziła, iż jest to obowiązek instytucjonalny. Stopniowo rośnie liczba inicjatyw, które w mniej lub bardziej stanowczy sposób skłaniają badaczy do zamieszczania materiałów w otwartych zasobach Internetu. Nakaz taki wydaje się coraz bardziej akceptowany przez środowisko naukowe. Większość polskich naukowców popiera wprowadzenie obowiązku zamieszczania wyników wszystkich badań naukowych, finansowanych ze środków publicznych w modelu otwartym, czy też wprowadzenie przez instytucje finansujące badania obowiązku umieszczania w otwartym dostępie publikacji powstałych w ramach finansowanych przez nie projektów, lub wprowadzania przez uczelnie obowiązku udostępniania publikacji naukowych autorstwa swoich pracowników w uczelnianych repozytoriach (Szprot, red., 2014, 94).

Rozwiązaniami, które pozwalają na gromadzenie w otwarty sposób treści naukowych mogą być m.in. repozytoria, platformy czasopism, biblioteki cyfrowe. Polscy naukowcy mogą deponować swoje prace w repozytoriach własnej instytucji, repozytoriach dziedzinowych, otwartych repozytoriach zewnętrznych (także zagranicznym) np.w Repozytorium Centrum Otwartej Nauki ${ }^{10}$, które jest dostępne dla wszystkich polskich naukowców, niezależnie od dyscypliny i afiliacji.

W badaniach EP najwięcej instytucji praktykujących model OA wykorzystuje własne repozytoria instytucjonalne (prawie 65\% respondentów) lub zewnętrzne repozytoria (blisko $50 \%)$. Stronę domową pracownika wykorzystuje ponad 1/4 instytucji. Dla porównania, w opinii indywidualnych naukowców preferowanym miejscem zamieszczania swoich prac w OA są otwarte czasopisma (stwierdziło tak 70\% badaczy), 31\% naukowców umieszcza publikacje w zagranicznych repozytoriach, w polskich $18 \%$. Z perspektywy instytucjonalnej, wykorzystanie otwartych repozytoriów jest większe niż w opiniach indywidualnych badaczy. Również poszczególni badacze wykorzystują strony domowe własne lub instytucji w celu archiwizacji swojego dorobku (Szprot, red., 2014, 96).

Dwa kluczowe zagadnienia pozwalające zmierzyć w jakim stopniu pracownicy polskich instytucji naukowych zamieszczają wyniki swoich prac badawczych (publikacji i danych) w zasobach otwartego Internetu, to pytanie zadane w ankiecie badania EP o umieszczanie publikacji w OA oraz pytanie o udostępnianie danych badawczych wykorzystując publiczne licencje. 52\% instytucji nie publikuje w OA i 82\% jednostek nie uwidacznia swoich danych badawczych. Zbadano, czy występuje zależność między tymi zmiennymi. Zarówno instytucje, w których publikuje się i nie publikuje w OA, w większości przypadków nie stosują licencji typu Creative Commons. Jednak nieco więcej jest instytucji publikujących w OA i wykorzystujących publiczne licencje do upowszechniania danych badawczych, niż instytucji niepublikujących w OA i korzystających z tych licencji. Zatem publikowanie w OA sprzyja wykorzystaniu publicznych licencji do uwidaczniania danych. Silniejsza zależność uwidacznia się w przypadku wpływu zmiennej określającej wykorzystanie publicznych licencji na zmienną definiującą publikowanie w zasobach OA. Instytucje użytkujące publiczne licencje do uwidaczniania danych badawczych w większości publikują w OA, natomiast

${ }^{10}$ http://www.depot.ceon.pl/ 
te jednostki, które nie wykorzystują publicznych licencji w niemal równym stopniu publikują w OA, jak i tego nie robią (z nieco większym naciskiem na publikację). Zatem można stwierdzić, iż fakt stosowania przez instytucje publicznych licencji do uwidaczniania danych badawczych, sprzyja zamieszczaniu publikacji naukowych w otwartych zasobach.

W polskich instytucjach badawczych można zauważyć, iż zamieszczanie materiałów w otwartych zasobach Internetu, czy to publikacji czy danych źródłowych, nie jest powszechną praktyką, ale też nie można stwierdzić, że zupełnie nie występuje. Bardziej naukowcy są jednak skłonni umieszczać wyniki swoich prac badawczych w postaci publikacji, niż udostępniać szerokiej publiczności w swobodny sposób źródłowe dane badawcze.

\subsection{Opinie na temat zamieszczania danych i publikacji w otwartych zasobach}

Świadomość korzyści, jakie może nieść ze sobą zamieszczanie publikacji w otwartym dostępie, wydaje się być coraz większa wśród polskich naukowców. Przedstawiciele instytucji, jako główną korzyść dla swoich jednostek i pracowników, wskazywali możliwość dotarcia do szerszej grupy odbiorców (88\% wskazań), zwiększenie liczby cytowań (69\%), rozwój współpracy między badaczami (67\% respondentów) i komunikacji w środowisku (59\%) (zob. Rys. 1) ${ }^{11}$.

Rys. 1. Korzyści z zamieszczania publikacji naukowych w OA

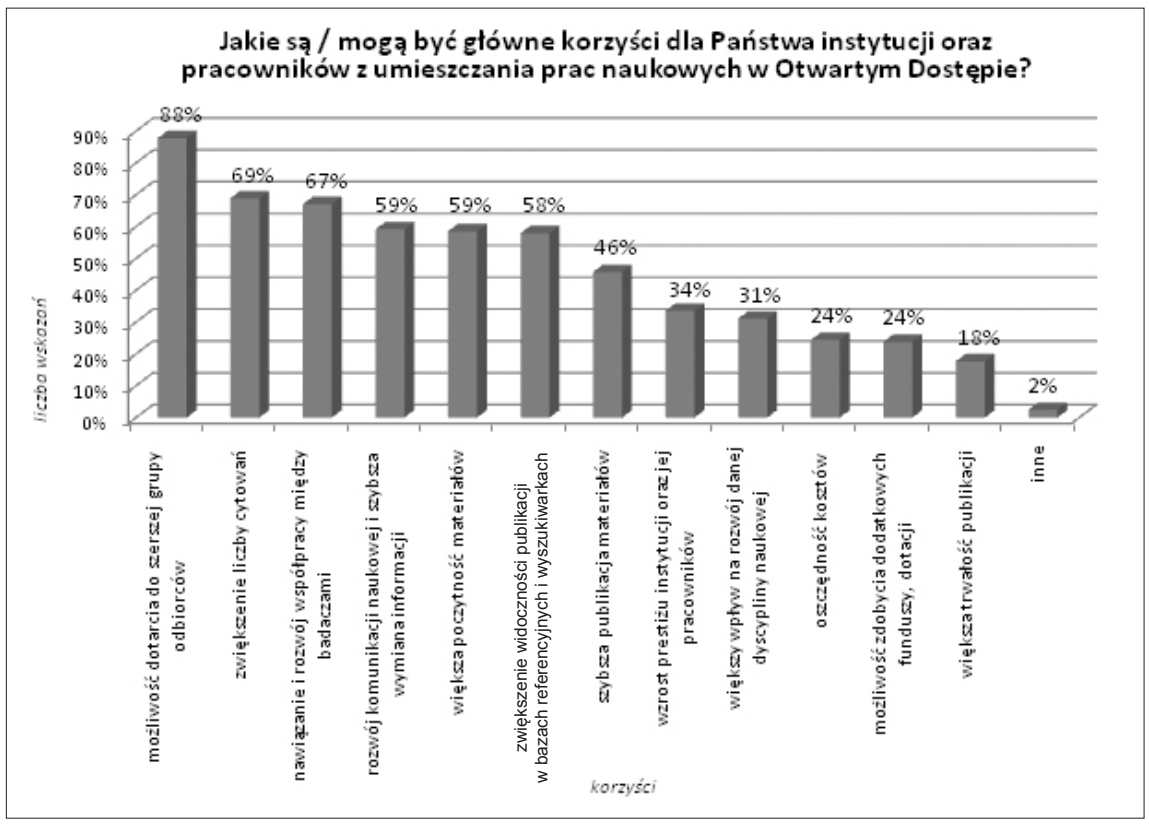

Źródło: opracowanie własne.

11 Podobne opinie kształtowały się wśród badaczy uczestniczących w badaniach opinii naukowców, zob. (Szprot, red., 2014, 91). 
Określając przeszkody, które zniechęcają do wykorzystywania OA, respondenci najczęściej wskazywali niejednolite kwestie praw autorskich, dodatkowe koszty i dodatkową pracę oraz wątpliwą jakość materiałów (zob. Rys. 2) $)^{12}$.

Rys. 2. Przeszkody zniechęcające do publikowania w OA

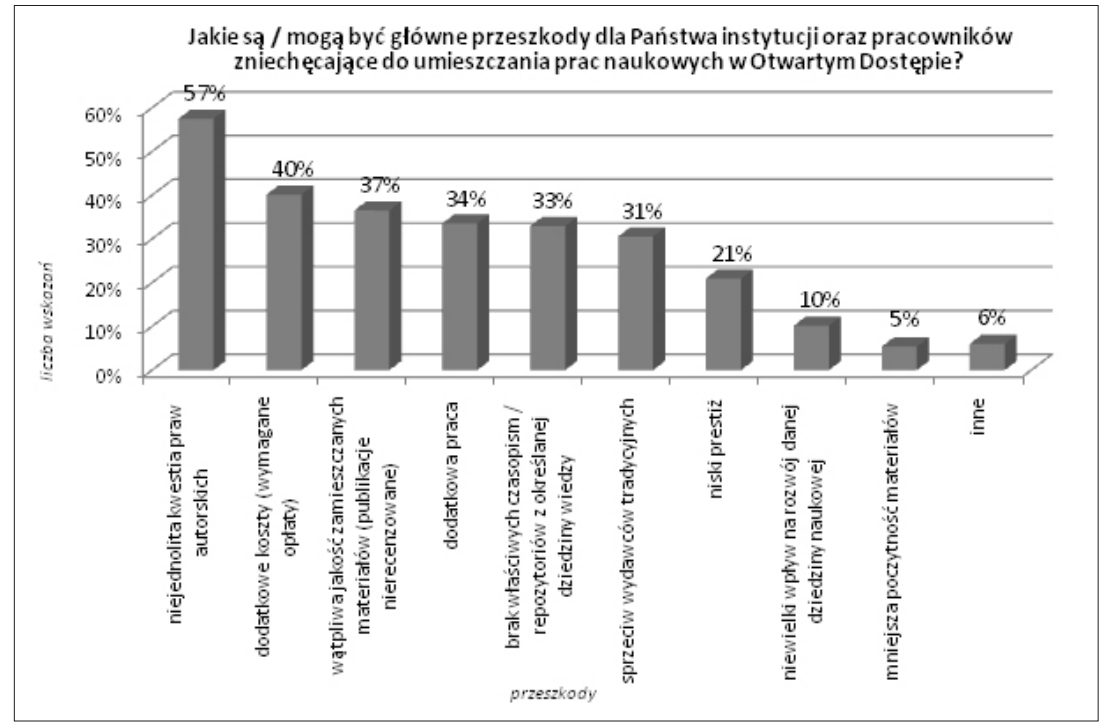

Źródło: opracowanie własne.

Około 80\% wszystkich respondentów biorących udział w badaniu EP określiło korzyści i/lub przeszkody w zamieszczaniu publikacji w Open Access. Średnio wskazywano więcej korzyści niż przeszkód. Wydaje się zatem, iż w świadomości pracowników polskich instytucji naukowych, występuje przekonanie o pożytku jaki wiąże się z publikowaniem prac w OA, jednak przeszkody, chociaż mniej sprecyzowane, nadal wpływają na ostrożne podejście i częstą rezygnację z publikacji w OA.

Około 71\% instytucji wyraziło swoje zainteresowanie uczestnictwem w projekcie stworzenia centralnego międzyinstytucjonalnego repozytorium danych badawczych. Jednak dosyć spora grupa $28 \%$ instytucji nie chce uczestniczyć w tym przedsięwzięciu.

Sprawdzono jakie czynniki mogą mieć wpływ na deklarowane zaangażowanie w projekt powszechnej dostępności danych badawczych. Czy to, iż instytucja publikuje w OA znalazło odzwierciedlenie w opiniach na temat projektu? Okazało się, że w grupie instytucji publikujących w OA nieco więcej jednostek wskazało chęć zaangażowania w projekt, niż wśród instytutów niepublikujących w OA. Analogicznie więcej odpowiedzi o braku zaangażowania w projekt było wśród instytutów niewykorzystujących OA niż w tych, korzystających z tego modelu. Wprawdzie różnice te nie są duże i raczej nie można mówić w tym przypadku o widocznej zależności, jednak stwierdzenie, iż publikowanie

12 W opinii naukowców pojawiają się dodatkowo stwierdzenia, iż otwarty dostęp jest niekorzystny dla wydawnictw naukowych oraz że nie można go pogodzić z prestiżem publikacji, zob. (Szprot, red., 2014, 92). 
w OA sprzyja przychylnemu podejściu do projektu powszechnej dostępności danych nie jest nadinterpretacją.

Także instytucje upubliczniające swoje dane badawcze z wykorzystaniem publicznych licencji w większości wyrażały swoją chęć zaangażowania w omawiany projekt. Jednostki niekorzystające z publicznych licencji określiły swoje zaangażowanie, ale już w mniejszej liczbie. Można wnioskować, iż stosowanie publicznych licencji także wpływa korzystnie na zaangażowanie w projekt międzyinstytucjonalnego repozytorium danych badawczych.

Podobna sytuacja, jak opisana powyżej, kształtuje się w przypadku deklaracji dotyczących łączenia publikacji z danymi badawczymi, na bazie których je opracowano. Jednostki stosujące tę praktykę w większości chcą uczestniczyć w projekcie, instytucje nie łączące danych z publikacjami deklarują zaangażowanie w mniejszej liczbie. Doświadczenia związane $\mathrm{z}$ otwartymi zasobami Internetu, jakie do tej pory zostały wypracowane w instytucjach, czyli publikowanie w zasobach OA i/lub wykorzystywanie publicznych licencji do upowszechniania danych badawczych i/lub stosowanie praktyki łączenia danych badawczych z publikacjami, sprzyjają deklaracji zaangażowania w projekt powszechnej dostępności danych badawczych.

\subsection{Wzmocnione publikacje}

Około 3/4 polskich instytucji uczestniczących w badaniu EP deklaruje stosowanie praktyki łączenia źródłowych danych badawczych z publikacjami opracowanymi na ich podstawie. Około 23\% jednostek nie realizuje takich działań. Jeżeli instytucje łączą dane badawcze z publikacjami, głównie dzieje się to poprzez zamieszczanie jedynie informacji o dostępie do danych w publikacji (68\% instytucji). Ten sposób łączenia danych z publikacjami jest dosyć daleki od modelu wzmocnionych publikacji, który polega na zamieszczaniu w otwartych zasobach Internetu cyfrowych postaci danych i publikacji. Około $28 \%$ instytucji wskazało, iż realizuje taki sposób łączenia danych. Wprawdzie większość instytucji deklaruje łączenie danych z publikacjami, lecz głównie stosowane są rozwiązania pośrednie polegające na zamieszczaniu jedynie informacji o dostępie do danych, a nie cyfrowych obiektów w otwartych zasobach.

Zbadano również, czy występuje relacja między publikowaniem prac naukowych w otwartych zasobach Internetu a stosowaniem praktyki łączenia danych badawczych z publikacjami. Bez względu na to, czy instytucje publikują w OA czy nie, wskazywały one w większości przypadków, iż dane badawcze w ich instytucji są łączone z publikacjami. Jednak w przypadku publikowania w OA więcej instytucji wiąże dane badawcze z publikacjami niż w przypadku instytucji niepublikujących w OA. Można stwierdzić, iż brak jest wyraźnej korelacji, jednak zamieszczanie publikacji w OA sprzyja tworzeniu powiązań między danymi a publikacjami. Korelacja występuje natomiast w drugiej opisywanej sytuacji. Instytucje, które stosują praktykę łączenia danych badawczych z publikacjami, w większości przypadków umieszczają materiały w zasobach OA. Natomiast instytucje nie łączące danych z publikacjami w większości nie publikują w OA. Można zatem wyciągnąć wniosek, że stosowanie praktyki łączenia danych badawczych z publikacjami wiąże się z użytkowaniem modelu OA. Natomiast w instytucjach, które nie łączącą danych z publikacjami, większe jest prawdopodobieństwo, iż nie publikują w otwartych zasobach Internetu.

Odpowiedzi na pytanie o miejsce przechowywania danych w instytucji w dużym stopniu obrazują sposób zarządzania zasobami danych badawczych. Poddano analizie relację 
między sposobem przechowywania danych a stosowaniem praktyki powiązania danych badawczych z publikacjami. Niezależnie od wskazanego sposobu przechowywania danych większość instytucji określiła, iż dane w ich jednostkach są powiązywane z publikacjami. Jednak instytucje przechowujące dane w zamkniętych zasobach częściej wskazywały, iż nie wiążą danych z publikacjami, niż te archiwizujące w otwartych zasobach. Bez względu na stwierdzenie wiązania danych z publikacjami lub nie, instytucje wskazywały głównie na przechowywanie danych w zamkniętych zasobach własnych instytucji.

\section{Wnioski}

Rozwój komunikacji naukowej nieodłącznie będzie wiązał się z wykorzystaniem nowych technologii i środowiska Internetu. Pociąga to za sobą wzrost znaczenia idei Otwartej Nauki, która to bazuje na narzędziach informatycznych pozwalających na pokonywanie barier czasu i miejsca, umożliwiających łatwą i szybką wymianę myśli. Otwarty model nauki jest dziś popierany na świecie przez wiele instytucji odpowiedzialnych za prowadzenie polityki w obszarze nauki. Także w coraz większej mierze poszczególne instytucje naukowe i badawcze oraz ciała finansujące badania przyjmują ten model, zobowiązując swoich pracowników do udostępniania wyników badań zgodnie z jego regułami.

W Polsce Otwarta Nauka realizowana jest głównie na poziomie otwartego dostępu do publikacji naukowych. Nie jest to jednak zjawisko na tyle powszechne, by dorównywało skali europejskiej, czy praktykom płynącym z zachodu. Badania poziomu wykorzystania modelu Open Access pokazują, iż ok. 50-60\% polskiego środowiska naukowego praktykuje zamieszczanie swoich publikacji w otwartych zasobach Internetu. Stopniowo wzrasta poparcie dla idei OA, akceptowane są przedsięwzięcia i działania zmierzające do rozszerzenia ruchu, jednak praktyczna realizacja jego zasad przychodzi ciężej.

Otwarte dane badawcze niemalże nie występują w Polsce. Z reguły dane uzyskane w wyniku prac badawczych są przechowywane wewnątrz instytucji i dostępne są jedynie dla jej pracowników. Dodatkowo są one zapisywane w formatach zamkniętych, utrudniających ich ponowne wykorzystanie. Zarządzanie danymi badawczymi w większości odbywa się w sposób mało usystematyzowany i raczej zdecentralizowany. Preferowane są rozwiązania polegające na samodzielnej odpowiedzialności poszczególnych pracowników i przechowywaniu danych w obrębie instytucji macierzystej. Wprawdzie deklarowane są chęci udostępniania danych badawczych szerszemu gronu do ponownego użytkowania, jednak głównie dzieje się to za pomocą kanałów wymagających osobistych kontaktów i indywidualnych ustaleń, a nie rozwiązań pozwalających na swobodne działanie np.pobieranie danych z repozytoriów czy stron WWW.

Jeżeli dane badawcze są łączone z publikacjami opracowanymi na ich podstawie dzieje się to w większości przypadków jedynie poprzez zamieszczanie informacji w publikacji o istnieniu takich danych. Ten sposób łączenia danych z publikacjami jest dosyć daleki od modelu wzmocnionych publikacji, który polega na zamieszczaniu i łączeniu w sieci wzajemnych powiązań cyfrowych postaci publikacji, danych i dodatkowych materiałów. Zatem daleka jeszcze droga do tworzenia i wykorzystania wzmocnionych publikacji, mimo wykazywanych pozytywnych opinii na temat modelu OA oraz projektu utworzenia centralnego międzyinstytucjonalnego repozytorium danych badawczych. 
Polskie środowisko naukowe powinno dążyć do rozwoju i zmiany obecnie funkcjonującego modelu komunikacji naukowej, aby nadążać za tendencjami światowej nauki, której chcemy być częścią. Nie uda to się jednak bez zaangażowania na wielu poziomach, począwszy od władz państwowych, władz instytucji naukowych, kończąc na samych naukowcach.

\section{Bibliografia}

Adriaansen, D.; Hooft, J. (b.d.) Properties of enhanced publications and the supporting tools, [online] [24.02.2015], http://www.cs.uu.nl/docs/vakken/mdic/papers/Adriaansen-fin.pdf

Bednarek-Michalska, B. (2012). Repozytoria surowych danych - dlaczego biblioteki powinny je znać? Biuletyn EBIB [online], 8 (135), [10.03.2015], http://www.nowyebib.info/images/stories/ numery/135/135_michalska_.pdf

Bednarek-Michalska, B. (2013). Otwarte dane surowe. Kraków: Pedagogiczna Biblioteka Cyfrowa. [online], [10.03.2015], http://pbc.up.krakow.pl/dlibra/docmetadata?id=3467\&from=publication

Dmochowska, H., red. (2013). Rocznik statystyczny Rzeczypospolitej Polskiej 2013. Warszawa: Zakład Wydawnictw Statystycznych.

Dmochowska, H., red. (2014). Rocznik statystyczny Rzeczypospolitej Polskiej 2014. Warszawa: Zakład Wydawnictw Statystycznych. [online] [24.02.2015], http://stat.gov.pl/obszary-tematyczne/roczniki-statystyczne/roczniki-statystyczne/rocznik-statystyczny-rzeczypospolitej-polskiej-2014,2,9.html

Federacja Bibliotek Cyfrowych. [online], [04.03.2015], http://fbc.pionier.net.pl/owoc/list-libs

Godtsenhoven, K., van et al. (2009). Emerging Standards for Enhanced Publications and Repository Technology: Survey on Technology. [online], Amsterdam: Amsterdam University Press, [24.02.2015], http://dare.uva.nl/cgi/arno/show.cgi?fid=150752

Hofmokl, J. et al. (2009). Przewodnik po otwartej nauce. Warszawa: ICM. [online], [03.03.2015], http://creativecommons.pl/wp-content/uploads/2012/06/Przewodnik_Po_Otwartej_Nauce.pdf

Horizon 2020 (2013). Guidelines on Data Management in Horizon 2020, [online], European Commission. Horizon 2020. The EU Framework Programme for Research and Innovation, [04.03.2015], http://ec.europa.eu/research/participants/data/ref/h2020/grants_manual/hi/oa_pilot/h2020-hi-oa-data-mgt_en.pdf

Kozierski, P. et al. (2013). Open Access. Analiza zjawiska z punktu widzenia polskiego naukowca. Poznań-Kraków: Impuls. [online] [03.03.2015], https://depot.ceon.pl/bitstream/handle/123456789/2513/Open\%20Access.pdf

Nahotko, M. (2010). Komunikacja naukowa w środowisku cyfrowym: globalna biblioteka cyfrowa w informatycznej infrastrukturze nauki. Warszawa: Wydaw. SBP.

OECD (2007). Principles and Guidelines for Access to Research Data from Public Funding [online]. The Organisation for Economic Co-operation and Development (OECD), [04.03.2015], http:// www.oecd.org/science/sci-tech/38500813.pdf

Open Data (2012). Open Data Handbook Documentation. Release 1.0.0. [online], [24.02.2015], http:// opendatahandbook.org/

Szprot, J., red. (2014). Otwarta nauka w Polsce 2014. Diagnoza. Warszawa: Wydaw. ICM. [online], [03.03.2015], http://pon.edu.pl/index.php/nasze-publikacje

Verhaar, P. (2009). Object Models and Functionalities. In: Vernooy-Gerritsen M. (eds.) Enhanced Publications. Linking Publications and Research Data in Digital Repositories [online], Amsterdam: University Press, 93-129, [25.06.2015], http://dare.uva.nl/cgi/arno/show.cgi?fid=150723

Vernooy-Gerritsen, M., ed. (2009). Enhanced Publications: Linking Publications and Research Data in Digital Repositories. Amsterdam: Amsterdam University Press, [online] [24.02.2015], http:// dare.uva.nl/cgi/arno/show.cgi?fid=150723 


\title{
Enhanced Publications: a New Model of Supporting Scholarly Communication
}

\begin{abstract}
Purpose/thesis: The paper presents the concept of enhanced publications that may influence the improvement and optimization of scientific communication. Enhanced publications are complex digital objects that contain various types of publications, such as books, articles, reports together with additional materials used in them, including raw research data, videos, audio records, algorithms, plans, models, comments and other materials.

Approach/methods: The primary objective of the research survey addressed to Polish scientific and research-development units was to determine the knowledge level and the use of enhanced publications. Different methods of research data management concerning the production, storage and deposition of research data have been defined. The paper also presents the researchers' opinions on the Open Access model.

Results and conclusions: The creation of enhanced publications is not a commonly undertaken activity in Polish scientific institutions. Although the majority of institutions declare they link research papers to the source data used within, they do that by adding information about access to the data, not by depositing the digital objects in open archives (repositories).

Originality/value: The research survey is a part of the project developed and implemented in the countries of the Visegrád Group. The aim of the project was to characterize the specificity of scholarly communication in the member countries and to identify directions of development. The paper presents the concept of the enhanced publications that is relatively little known in Polish scientific community.
\end{abstract}

\section{Keywords}

Enhanced publications. Open Access. Open Data. Scholarly communication.

mgr EDYTA KĘDZIERSKA ukończyła studia magisterskie w instytucie Informacji Naukowej i Studiów Bibliologicznych Uniwersytetu Warszawskiego oraz studia licencjackie na kierunku Socjologia na Uniwersytecie Warszawskim. Od 2011 roku bibliotekarz w Oddziale Udostępniania i Przechowywania Zbiorów w Bibliotece Gtówne PW. Jej zainteresowania skupiaja się wokót statystyki bibliotecznej oraz analizy efektywności i jakości pracy bibliotek. Wspótpracuje z Zespotem SBP ds. analizy funkcjonowania bibliotek. Najważniejsze publikacje: (1) E. Kędzierska, J. Sobielga, A. Zawatkiewicz: Nowa jakość w badaniach użytkowników bibliotek. Bibliotekarz 2015, nr 1, s. 12-15. (2) E. Kędzierska, A. Zawatkiewicz: Jak przeprowadzić badania satysfakcji użytkowników biblioteki? Poradnik dla bibliotekarzy. Warszawa, 2014. W: Analiza Funkcjonowania Bibliotek [online], [19.01.2014], http://pliki.sbp.pl/afb/jak-przeprowadzic-badania-satysfakcji.pdf (3) E. Kędzierska, A. Zawatkiewicz: Potrzeby szkoleniowe bibliotekarzy w zakresie statystyki bibliotecznej. Biuletyn EBIB 2014, nr8 (153), Edukacja i rozwój osobisty bibliotekarzy [online], [19.01.2014], http://open. ebib.pl/ojs/index.php/ebib/article/view/283/466 (4) Ocena Systemu Biblioteczno-Informacyjnego Politechniki Warszawskiej - metodyka badań, E. Kędzierska et al. W: Znaczenie i badania jakości w bibliotekach: VKonferencja Biblioteki Politechniki Łódzkiej, Łódź-Rogów, 13-15 czerwca 2012 r: materiaty konferencyjne, Łódź 2012, s. 147-170. (5) Sprawozdanie Zespotu ds. oceny funkcjonowania Systemu Biblioteczno-Informacyjnego Politechniki Warszawskiej, [oprac. Elżbieta Gruszczyńska et al.], Biblioteka Gtówna Politechniki Warszawskiej, Warszawa 2012.

Kontakt $z$ autorka:

E.Kedzierska@bg.pw.edu.pl

Biblioteka Gtówna Politechniki Warszawskiej

Plac Politechniki 1

00-661 Warszawa 